\title{
ELABORASI ANALISIS PEMBIAYAAN DALAM MEMINIMALISIR NON PERFORMING FINANCE (NPF) PADA LEMBAGA KEUANGAN SYARIAH
}

\author{
Kharis Fadlullah Hana1, Ridwan², Enggar Arrosyad Chodlir ${ }^{3}$ \\ 123Institut Agama Islam Negeri Kudus \\ $\triangle$ kharis@iainkudus.ac.id ${ }^{1}, \bigotimes$ ridwan@iainkudus.ac.id ${ }^{2}$ \\ \arrosyadmobile@gmail.com ${ }^{3}$
}

Abstrak: Kualitas pembiayaan merupakan faktor penting yang menentukan tingkat kesehatan lembaga keuangan syariah. Meskipun demikian, lembaga sering menganalisis pembiayaan secara kurang tepat. Tujuan penelitian ini menyajikan model analisis pembiayaan yang tepat dalam memberikan rekomendasi pembiayaan. Hal itu dapat mencegah tingginya Non Performing Finance (NPF). Metode penelitian yang dilakukan adalah Research and Development berdasarkan hasil riset dari beberapa lembaga keuangan syariah. Peneliti mengambil sampel dari Bank Syariah, BPR Syariah dan Koperasi Simpan Pinjam dan Pembiayaan Syariah (KSPPS). Hasil penelitian menunjukkan bahwa Bank syariah dan BPR Syariah telah menentukan formula analisis yang cukup lengkap, namun dari KSPPS kurang memiliki formula yang lengkap. Hasilnya, peneliti menemukan aspek baru yang semula pada umumnya adalah $5 \mathrm{C}$, yakni dengan menggunakan tambahan menjadi 8C. Aspek tersebut adalah character, collateral, capacity, capital, condition of economy, constrain, cash flow dan closeness. Kontribusi penelitian ini memberikan aspek baru bagi lembaga keuangan syariah agar dapat memberikan keputusan pembiayaan lebih akurat.

\section{Kata kunci: Analisis Pembiayaan, NPF, Lembaga Keuangan Syariah}

\section{LATAR BELAKANG}

Analisis pembiayaan merupakan faktor penting dalam mendukung tingkat kesehatan Bank Syariah. Hal itu disebabkan karena analisis merupakan langkah awal untuk mencegah terjadinya pembiayaan macet (Ali \& Miftahurrohman, 2016). Nasabah sebagai pihak penerima pembiayaan dapat mengemukakan sejuta alasan atas pembiayaan yang macet tersebut (Puspitasari \& Singgih, 2011). Pada sisi yang lain, Bank syariah harus membayar dana masyarakat yang ditempatkan padanya dan biaya operasional perusahaan. Apapun yang terjadi terhadap pembiayaan, bank syariah tidak boleh tidak membayar dana nasabah. Maka, ketepatan dalam menganalisis proposal pembiayaan, analisis pembiayaan, dokumentasi, pencairan dana dan pemantauan pembiayaan sangat perlu dilakukan. Seringkali kebijakan pemberian pembiayaan tanpa didukung dengan analisis pembiayaan yang akurat. Hal ini dipengaruhi oleh beberapa faktor yaitu target pembiayaan perbulan yang tinggi yang ditetapkan oleh Bank, keputusan analis atas dasar kedekatan secara personal dan kurangnya pengetahuan analisis pembiayaan yang benar (Lusian, Siregar, \& Maulana, 2014).

Pengetahuan analisis pembiayaan yang tepat harus didasari dengan teori dan metode pengukuran yang jelas. Secara umum, analisis pembiayaan terbagi menjadi dua aspek penting. Aspek Pertama adalah aspek kuantitatif dan aspek kedua adalah aspek kualitatif (Yusuf, 2014). Dua Aspek tersebut disebutkan diberbagai 
buku analisis kredit, namun belum dibukukan secara jelas pada analisis pembiayaan. Padahal analisis kredit sangat berbeda dengan analisis pembiayaan. Analisis kredit hanya memperhitungkan angka dan hubungan antar manusia, sedangkan analisis pembiayaan disamping angka dan hubungan manusia ditekankan juga hubungan manusia dengan Tuhan. Ada akad mudhorobah, musyarakah, murabahah, ijarah dan akad lainnya yang tidak terdapat pada buku analisis kredit yang hal itu sangat penting untuk diperhitungkan pada analisis pembiayaan. Berdasarkan hal itu maka, pedoman analisis pembiayaan berupa bahan ajar sangat perlu di buat guna mendukung mata kuliah praktik analisis pembiayaan. Dan juga sebagai pedoman bagi perusahaan dalam melakukan analisis yang tepat sebagai pencegah pembiayaan bermasalah dan meningkatkan tingkat kesehatan Bank Syariah.

\section{TEORI DAN METODE}

\subsection{Pembiayaan Bank Syariah}

Berdasarkan penelitian (Susilo, Hubeis, \& Purwanto, 2012) kendala dalam penyaluran pembiayaan adalah pengetahuan masyarakat yang minm tentang pola bagi hasil, resiko besar dikarenakan sangat ditentukan oleh kejujuran nasabah dalam menyampaikan hasil usahanya secara transparan. Variabel utama dalam analisis pembiayaan yang dikemukakan (Puspitasari \& Singgih, 2011) adalah kondisi usaha menjadi prioritas tertinggi dalam pengambilan keputusan pembiayaan. Perbedaan antara analisis kredit dan pembiayaan pada penelitian (Djuarni, 2011) yaitu pada penentuan besarnya pembiayaan. Pada Bank Jabar Konvensional menggunakan metode perputaran modal kerja, sedangkan pada Bank Jabar Syariah untuk menentukan evaluasi kebutuhan musyarakah dengan metode analisis arus kas.

Penelitian lainnya pada pemberian pembiayaan pada Bank Syariah Mandiri cabang Manado (Pato, 2013) adalah secara keseluruhan menggunakan teori yang ada yaitu 5C (character, capacity, collateral, capital, condition), 7 P (personality, party, purpose, prospect, payment, profitability, protection). Apabila nasabah mempunyai pinjaman dari Bank lain maka analis langsung menggunakan BI checking sebagai langkah awal sebelum melakukan analisis lebih lanjut.

Sedangkan untuk pembiayaan bermasalah menurut penelitian (Firdaus, 2015) pertumbuhan pembiayaan berpengaruh positif tidak siginfikan terhadap pembiayaan bermasalah, CAR dan GDP berpengaruh positif signifikan terhadap pembiayaan bermasalah. Penelitian lainnya (Arifah, 2017) menyatakan bahwa pembiayaan mudharabah dapat menjadi bermasalah dikarenakan faktor eksternal dan internal. Penanganan pembiayaan bermasalah dilakukan metode 3R yaitu rescheduling, reconditioning dan restructuring. Sedangkan upaya lain dinyatakan pada penelitian (Ibrahim \& Rahmawati, 2017) tentang kebijakan penyelesaian pembiayaan bermasalah pada BMI dilakukan melalui OTS, penagihan, somasi, restrukturisasi, penjualan jaminan, write off, dan adanya penetapan denda serta pembentukan tim khusus dalam menangani pembiayaan bermasalah.

\subsection{Metode Penelitian}

Penelitian ini merupakan penelitian deskriptif dengan menggunakan pendekatan kualitatif. Sumber data yang digunakan dalam penelitian ini yaitu sumber data primer dan sumber data sekunder. Data Primer diperoleh dari 7 Lembaga keuangan syariah yakni, Bank Syariah Indonesia (BSI) cabang Kudus, 
BPRS Saka Dana Mulia, BPRS Artha Mas Abadi Pati, BMT Mubarakah Undaan, BMT Mitra Muamalat Kudus, BMT Ar Raudloh Blora, BMT Al-Amin Ngembalrejo Bae Kudus. Data primer diperoleh melalui wawancara secara langsung dan pengamatan lapangan dengan beberapa informan, sedangkan data sekunder dalam penelitian ini diperoleh melalui jurnal-jurnal, artikel, dan berbagai dokumentasi dari subjek penelitian. (Idrus, 2009) Adapun teknik pengumpulan data dalam penelitian ini dilakukan melalui observasi, wawancara, dan dokumentasi (Nugrahaini, 2014) Sedangkan teknik analisis data yang digunakan dalam penelitian ini adalah analisis kualitatif yang mencakup reduksi data, penyajian data, dan penarikan kesimpulan (Sugiyono, 2013).

\section{HASIL DAN PEMBAHASAN}

\subsection{Hasil Penelitian}

Penelitian ini dilakukan pada beberapa lembaga keuangan syariah yakni Bank Syariah Indonesia (BSI) cabang Kudus, BPRS Saka Dana Mulia, BPRS Artha Mas Abadi Pati, BMT Mubarakah Undaan, BMT Mitra Muamalat Kudus, BMT Ar Raudloh Blora, BMT Al-Amin Ngembalrejo Bae Kudus.

\section{BSI Kudus}

Bank Syariah Indonesia Cabang Kudus memiliki strategi dalam melakukan analisis pembiayaannya yakni pada karakter calon nasabah mereka melakukan pengecekan dari data $i$ deep (BI Checking) (Allama \& Nugroho, 2021). Dari aplikasi tersebut pihak surveyor BSI dapat melihat record pembiayaan calon nasabah pernah masuk kolektabilitas 2 atau lebih apakah tidak. Apabila kolektabilas 2 lebih atau pernah dinyatakan bermasalah maka otomatis tidak lolos dalam analisis pembiayaan di awal. Pada data BI checking bukan hanya terlihat record pembiayaan bermasalah di Bank atau lembaga keuangan lainnya, tetapi record pembayaran online melaui aplikasi apabila ada tunggakan juga terliha. Pihak BSI juga melakukan konfirmasi ke rekan nasabah terkait bagaimana informasi perilaku dan integritas calon nasabah tersebut. Target pasar BSI kudus lebih mengarah kepada pembiayaan mitra guna yaitu pembiayaan potong gaji karyawan. Hal itu dirasa lebih aman dibandingkan dengan produk pembiayaan lainnya. Mereka bekerjasama dengan beberapa instansi baik Negeri, swasta maupun perusahaan BUMN. BSI melihat jumlah karyawan yang dipekerjakan dari perusahaan tersebut, apabila memenuhi kualifikasi maka mereka memberikan tawaran kerjasama berupa payroll gaji pembayaran karyawannya dengan keuntungan yakni mendapatkan program pembiayaan potong gaji dengan margin yang kompetitif. Beberapa perusahaan yang sudah kerjasama yakni Pemda Kudus, RS Aisyiyah, PT. KAI, IAIN kudus, dan beberapa instansi lainnya. Berdasarkan hasil taksiran kemampuan bayar BSI menaksir kemampuan bayar nasabah dari total gaji dikali dengan $80 \%$, jadi calon nasabah yang akan mengajukan pembiayaan dapat diterima apabila total angsurannya maksimal 80\% dari gajinya. Pihak BSI juga menganalisis kemampuan bayar calon nasabah melalui transasi rekening selama 3 bulan terakhir. Pada pembiayaan mikro usaha atau pembiayaan kerjasama untuk modal usaha, BSI mengukur modal calon nasabah melalui laporan keuangan selama 2 tahun terakhir. Mereka juga menganalisis perputaran arus kas pada usaha tersebut. Pada instrument analisis jaminan (collateral) di pembiayaan mitra guna adalah menggunakan SK PNS dan SK Pegawai tetap. Jaminan lainnya pada produk pembiayaan 
wholeshale, SME, pembiayaan konsumen dan pembiayaan mikro berupa Sertifikat tanah, gedung, rumah, BPKB kendaran. Namun, pada tahun ini BSI memiliki kebijakan untuk tidak menggunakan BPKB sebagai jaminan, hal itu karena harga kendaraan pada masa pandemi cukup fluktuatif sehingga menimbulkan resiko yang cukup tinggi(Allama \& Nugroho, 2021) .

Pada indikator condition of economy pihak BSI melakukan analisis top to down, mereka melihat variabel makro ekonomi yang terjadi saat itu, seperti kondisi pandemi memberikan dampak yang cukup pada pekerjaan bidang Dokter gigi, pariwisata dan yang lainnya. BSI melakukan analisis hambatan yang mungkin terjadi melalui pada produk pembiayaan apa yang digunakan. Pada produk pembiayaan mitra guna, hambatan yang terjadi adalah ketika karyawan yang melakukan pembiayaan potong gaji pindah tempat ke instansi yang baru, sehingga payroll dari instansi yang baru belum ada kesepakatan dengan BSI, apalagi dengan risiko jaminan yang tidak bisa diperjualbelikan yakni SK pengangkatan Pegawai baik PNS maupun swasta. Namun, BSI mengelola risiko tersebut dengan perjanjian diawal bahwa apabila pihak nasabah melakukan perpindahan kerja maka pembiayannya harus dilunasi terlebih dahulu. Dalam mencegah risiko lainnya BSI juga mempertimbangkan asal kementerian calon nasabah, pihak BSI akan meninjau kembali apabila calon nasabah berasal di bawah kementerian hukum dan HAM (kemenkumham) dan kementerian pertahanan (Allama \& Nugroho, 2021).

\section{BPR Syariah Artha Mas Abadi}

Pada BPR Syariah Arhat Mas Abadi pati telah melakukan analisis pembiayaan dengan cukup ketat. Mereka menambahkan metode pembiayaan yang semula 5C ditambahkan 1C yakni cashflow (Hidayatullah, 2021). Hal itu karena target pembiayaannya adalah usaha mikro kecil menengah (UMKM) dan pedagang kecil. Jadi, perlu diketahui arus kas yang dicapai oleh usaha tersebut. Untuk menilai karakter calon nasabah tersebut pihak BPRS melakukannnya melalui cara bertanya kepada orang-orang sekitarnya lebih dari satu narasumber yaitu orang yang dekat dengan nasabah, pihak yang bertentangan, dan pihak yang netral. Kemudian dari hasil survei tersebut dilakukan seleksi atau analisis terhadap nasabah dengan tidak dilihat dari segi kekayaan saja, tapi benar-benar orang yang komitmen dan amanah. Dalam menyetujui pengajuan pembiayaan, pihak BPRS harus tahu berapa jumlah pembiayaan yang benar-benar dibutuhkan calon nasabah. Ketika pembiayaan sudah diberikan harus dilakukan pemantauan. Agunan harus mengcover dari jumlah pembiayaan yang diajukan nasabah. Melakukan pemantauan setiap bulan dilihat dari angsuran apakah nasabah dalam membayar angsuran setiap bulannya lancar atau tidak. Ketika diketahui terdapat keterlambatan maupun tidak lancarnya nasabah membayar angsuran pembiayaan harus dideteksi dan ditanyakan kepada nasabah penyebabnya kenapa mengalami kesulitan dalam mengangsur pembiayaan (Hadi, 2021).

\section{BPR Syariah Saka Dana Mulia}

Produk pembiayaan pada BPR Syariah Saka Dana Mulia beraneka ragam yakni, pembiayaan mikro, pembiayaan jangka pendek, pembiayaan karyawan, gadai emas, pembiayaan perdagangan, pembiayaan multijasa dan pembiayaan dan pembiayaan haji dan umroh. Dalam menganalisis karakter nasabah pihak BPRS dapat melihatnya melalui BI Checking. BPRS juga melakukan survey keabsahan data pengajuan dengan hasil yang ada di lapangan. Seleksi 
pembiayaan yang diajukan oleh calon nasabah cukup ketat, dengan melihat nilai agunan yang dijaminkan dan kemampuan bayar dari calon nasabah. BPRS lebih melihat komitmen dari calon nasabah yang mengajukan dan sangat hatihati terhadap pembiayaan baru. Terbukti dengan proses pengajuan pembiayaan yang cukup lama sampai waktu pencairan. Mereka menggali data dari tetangga sekitar, apabila ada kejanggalan maka pihak BPRS meninjau kembali pengajuan pembiayaan bahkan sampai penolakan pembiayaan. Strategi itu dilakukan untuk meminimalisir tingkat pembiayaan bermasalah (Shella \& Butanto, 2021).

\section{BMT Mitra Muamalat}

Untuk mengetahui karakter calon anggota pembiayaan, pihak BMT melakukan wawancara singkat dengan mengamati apakah jawaban dari calon anggota kurang lancar, apabila kurang lancar berarti ada sesuatu yang disembunyikan. Untuk mengetahui lebih lengkap BMT menanyakannya kepada tetangga dan teman yang mengenal calon anggota tersebut. Berdasarkan informasi, karakter dapat berubah sesuai dengan kondisi maka diperlukan jaminan untuk mengikatnya, perubahan karakter anggota juga dipengaruhi oleh tetangga yang punya pengalaman (Arief, 2021).

BMT awalnya pembiayaan dengan nilai dibawah 1,5jt tanpa perlu jaminan, namun dengan beberapa anggota yang kurang lancar maka BMT membuat kebijakan terkait jaminan minimal KTP asli, KK Asli, Buku Nikah Asli. Apabila nominal pembiayaannya melebihi 1,5jt maka dengan jaminan BPKB atau sertifikat. Jaminan BPKB kendaraan pada BMT Mitra Muamalat mempertimbangkan tahun pembuatan minimal 5 tahun ke belakang dari sekarang. Pada jaminan sertifikat rumah atau tanah dilihat dari NJOP, apakah termasuk pada zona A, zona B, atau zona C. kebijakan nilai pembiayaan dari nilai jaminan sebesar 30\% sampai dengan 50\% dari nilai jaminan. BMT Mitra Muamalat menganalisis kemampuan calon anggota dengan menanyakan sisa hasil usaha setiap hari setelah dikurangi biaya (Arief, 2021) .

\section{BMT Al-Amin}

BMT al amin lebih memilih strategi bertahan dengan secara selektif memberikan rekomendasi pada calon anggota pembiayaan yang baru. Mereka lebih mengutamakan anggota yang lama dan rekomendasi calon anggota pembiyaan dari anggota lama. Tokoh masyarakat juga sebagai faktor pertimbangan dalam memberikan keputusan pembiayaan. BMT lebih mengutamakan sesorang yang memiliki pengaruh di daerahnya kemudian membuat target pasar berdasarkan tokoh tersebut. Surveyor dan marketingnya sudah lama menjadi karyawan ada yang mulai BMT berdiri pada tahun 2001 dan ada yang mulai tahun 2004 sampai tahun 2021 ini. hal itu menunjukkan bahwa BMT memberikan pelayanan yang bagus bagi karyawan dan anggota. Inilah yang menjadi faktor BMT tetap stabil di masa pandemi (Anwar, 2021).

Dalam meminimalisir risiko BMT lebih memilih dengan memberikan bagi hasil yang rendah melalui tabungan mudhorobah biasa, bukan dari simpanan mudhorobah berjangka. Hal itu karena dapat meningkatkan beban yang harus ditanggung BMT sehingga target pembiayaan tinggi dan mengakibatkan kurang selektifnya dalam menyalurkan pembiayaannya. Rata-rata pendapatan dari simpanan anggota berasal dari tabungan peserta didik siswa yang telah kerja sama dengan BMT. Namun, BMT belum memberikan rekomendasi pembiayaan kepada para guru yang bekerja di lembaga pendidikan tersebut. Itu terjadi 
karena BMT melihat penyusunan laporan keuangan dan pengelolaan yayasan pendidikan yang belum teratur dan efektif.

Segmentasi pembiayaan BMT al amin adalah pada pekerja proyek pembangunan yang membutuhkan modal usaha untuk mengerjakan proyeknya, seperti pembangunan gedung, jalan, jembatan dan perumahan. Pekerja itu merupakan relasi dari Manajer BMT dan relasi dari pengurus BMT. Segmentasi pasar lainnya adalah para masyarakat yang berdagang di lingkungan pabrik djarum dan beberapa masyarakat yang memiliki usaha. BMT lebih mengedepankan prinsip bagi hasil dengan akad mudhorobah. Analisis pembiayaannya melalui proyeksi keuntungan yang akan didapatkan selama 6 bulan kedepannya. Hasilnya kemudian dibagi setiap bulannya. Pembayaran bagi hasil sesuai dengan besaran proyeksi yang akan dicapai oleh nasabah tersebut (Anwar, 2021).

\section{BMT Ar Raudloh Blora}

Analisis pembiayaan yang dilakukan dalam meminimalisir risiko pada BMT Ar Raudloh melalui formulir laporan hasil pemeriksaan dan penilaian permohonan pembiayaan. Didalamnya terdapat aspek personal, jaminan, aspek keuangan, pertimbangan pendapat, usulan, catatan manager dan putusan pembiayaan. Pada aspek personal terdapat analisis karakter, hubungan dengan koperasi dan rekomendasi. Artinya BMT juga menganalisis calon anggota pembiayaan tersebut ada hubungan dengan BMT ataukah tidak. Hal itu akan memberikan informasi tambahan yang sangat penting. Hal lainnya adalah ada unsur rekomendasi, mereka melihat calon pembiayaan itu telah direkomendasikan dari siapa. Asek lainnya yang dianalisis secara rinci adalah aspek keuangan, yakni analisis laba rugi, labag bruto, laba bersih, biaya hidup dan angsuran lainnya. Temuan penting lainnya di BMT Ar Raudloh yakni setiap pengajuan pembiayaan harus di setujui oleh empat pihak, yakni marketing, manager kepala, manager dan pengurus. Hal itu berarti seleksi yang dilakukan oleh BMT cukup ketat karena melewati 4 bagian (Suratno, 2021).

\section{BMT Mubarakah}

Strategi analisis pembiayaan yang dilakukan di BMT Mubarakah adalah melalui analisis karakter, jaminan dan kemampuan calon anggota. BMT melihat karakter calon anggota melalui rekomendasi dari anggota lama yang telah mengambil pembiayaan di BMT. Pihak BMT cukup selektif dalam menilai karakter, mereka juga menggali informasi dari teman dan tetangga sekitarnya. Indikator lainnya dalam analisis pembiayaan yang dilakukan oleh BMT Mubarakah adalah jaminan, pada indikator jaminan, BMT mengharuskan kepada setiap calon nasabah yang mengajukan pembiayaan harus menyertakan jaminan mulai dari pembiayaan kecil dari Rp. 500.000,- sampai dengan pembiayan besar Rp.50.000.000,-. Hal ini yang menjadi strategi tersendiri bagi BMT mubarakah, mereka lebih mengedepankan keamanan pembiayaan melalui adanya pengikatan berupa jaminan atau agunan yang disertakan. Jaminan yang harus disertakan mulai dari pembiayaan dengan skala kecil adalah berupa KTP asli, KK asli. Taksiran jaminan yang bisa dijadikan landasan pembiayaan adalah sebesar 30\%-50\% dari nilai pasar. Pada unsur capacity (modal), pihak BMT mubarakah tidak terlalu rinci dalam melihat laporan keuangannya, karena banyak pedagang kecil yang tidak mempunyai laporan keuangan, mereka hanya memiliki nota penjualan dan 
pembelian. Indikator kemampuan calon anggota juga tidak terlalu dianalisis secara mendalam, cukup hanya melampirkan slip gaji dan rincian pendapatan perbulan apabila pedagang kecil karena rata-rata anggota pembiayaan di BMT Mubarakah adalah pedagang kecil dan petani. Pada analisis kondisi ekonomi, pihak BMT mempertimbangkan dampak pandemi pada usaha calon anggota, seperti pada calon anggota yang berprofesi pedagang, mereka hanya di rekomendasikan dengan jumlah pembiayaan kecil untuk meminimalisir risiko. Namun berbeda pada calon anggota yang berprofesi sebagai petani, mereka dapat diberikan pembiayaan secara optimal karena tidak terdampak pandemi (Ihsan, 2021).

\subsection{Pembahasan}

Lembaga Keuangan Syariah memiliki fungsi intermediasi sebagai penghimpun dana dan penyalur dana melalui pembiayaan. Dua fungsi utama tersebut menjadi sangat penting apabila dilaksanakan secara optimal terutama pada fungsi pembiayaan. Dengan pembiayaan yang besar maka akan menghasilkan keuntungan yang optimal. Hal itu terjadi juga apabila pembiayaannya adalah aman dan lancar. Untuk mencapai hasil pembiayaan yang aman dan lancar perlu dianalisis secara matang dan mendalam. Beberapa model analisis telah dilakukan di lembaga keungan mikro dan Bank syariah yakni 5C dan 7P. Hasil penelitian menyebutkan bahwa ada analisis lainnya yang digunakan oleh lembaga keuangan syariah yakni constrain (hambatan) dan Cash flow (arus kas). Peneliti juga menemukan metode lainnya berdasarkan data dari informan dan merumuskannya yakni Closeness (kedekatan). Sehingga peneliti merumuskan metode baru dalam menganalisis pembiayaan yakni menggunakan metode 8C dan 7P. Analisis 8C yakni, character, collateral, capacity, capital, condition of economy, constrain, cash flow dan closeness. Analisis 7P yakni, personality, party, purpose, prospect, payment, profitability dan protection. Penjelasan dari metode analisis pembiayaan $8 \mathrm{C}$ dan $7 \mathbf{P}$ yang ditemukan adalah sebagai berikut:

1) Character (karakter), merupakan sifat yang dimiliki sesorang terutama masalah keuangan. Untuk mengetahui karakter calon anggota pembiayaan, pihak BSI melakukan screening awal melalui BI Checking kemudian melakukan konfirmasi melalui telepon dan survey langsung kepada temannya. Pada BPRS dan BMT melakukan wawancara singkat dengan mengamati apakah jawaban dari calon anggota kurang lancar, apabila kurang lancar berarti ada sesuatu yang disembunyikan. Untuk mengetahui lebih lengkap BPRS dan BMT menanyakannya kepada tetangga dan teman yang mengenal calon anggota tersebut. Berdasarkan informasi, karakter dapat berubah sesuai dengan kondisi maka diperlukan jaminan untuk mengikatnya, perubahan karakter anggota juga dipengaruhi oleh tetangga yang punya pengalaman.

2) Collaterall (Jaminan), merupakan agunan yang dijaminkan kepada lembaga keuangan syariah sebagai pengikat pembiayaan. Pada Bank Syariah agunan bisa menggunakan SK PNS, SK Pegawai tetap, Sertifikat dan BPKB. pada lembaga keuangan mikro syariah BMT awalnya pembiayaan dengan nilai dibawah 1,5jt tanpa perlu jaminan, namun dengan beberapa anggota yang kurang lancar maka BMT membuat kebijakan terkait jaminan minimal KTP asli, KK Asli, Buku Nikah Asli. Apabila nominal pembiayaannya melebihi 1,5jt maka dengan jaminan BPKB atau sertifikat. Jaminan BPKB kendaraan pada BMT Mitra Muamalat mempertimbangkan tahun pembuatan minimal 5 tahun 
ke belakang dari sekarang. Pada jaminan sertifikat rumah atau tanah dilihat dari NJOP, apakah termasuk pada zona A, zona B, atau zona C. kebijakan nilai pembiayaan dari nilai jaminan sebesar 30\% sampai dengan $50 \%$ dari nilai jaminan.

3) Capacity (Kemampuan), merupakan kemampuan bayar calon anggota pengajuan pembiayaan. Kemampuan calon anggota dilihat dari sisa pendapatan setelah dikurangi dengan biaya hidup dan biaya tambahan lainnya. BMT Mubarakah memperhatikan segmen pembiayaan mikro dengan menanyakan yang tidak perlu ribet pada skala mikro, namun beda di BMT Mitra Muamalat dengan menanyakan sisa hasil usaha setiap hari setelah dikurangi biaya

4) Capital (Modal), merupakan modal yang dimiliki oleh calon nasabah atau anggota yang mengajukan pembiayaan. Pada komponen modal usaha diperhatikan seberapa rasio modal pemilik dibandingkan dengan total asset, seberapa rasio tingkat pengembalian modal dengan perhitungan ROE (return on equity), semakin tinggi ROE usaha nasabah maka semakin bagus tingkat hasil pengembalian modal. Di BSI menganalisis modal calon nasabah melalui laporan keuangan selama 2 tahun terakhir. Namun berbeda di lembaga keuangan mikro syariah, BMT cukup melihat modal yang dimiliki secara fisik dan keuangan.

5) Condition of Economy (Kondisi Ekonomi), merupakan situasi dan kondisi ekonomi yang ditinjau secara makro dan mikro. Situasi pandemi memberikan dampak yang cukup signifikan, hal itu membuat BSI melakukan kebijakan tidak menerima jaminan BPKB kendaraan. Pembiayaan pada sektor mikro cukup terdampak namun BMT dapat tetap bertahan karena pembiayaan mikro yang merata diberbagai daerah. Di segmen usaha di pasar nasabah cukup terdampak dengan pembayaran angsuran hanya mencapai $50 \%$, namun segmen lain pada pertanian menyokong beberapa anggota yang terdampak. Kondisi dalam menganalisis kondisi keluarga dan kondisi lingkungan.

6) Constrain (hambatan), merupakan hambatan yang mungkin mengganggu keberlangsungan usaha dan pendapatan pekerjaan. Pada BSI hambatan yang mungkin terjadi adalah apabila nasabah pindah kerja di tempat lain sehingga payrollnya belum bisa kerjasama dengan BSI, apalagi agunan yang disertakan adalah tidak bisa diperjualbelikan. Namun, BSI mengatasi hambatan tersebut dengan kesepakatan diawal harus melunasi pembiayaan apabila pindah kerja. Pada BPRS dan BMT dapat terjadi hambatan yang bisa diprediksi dan tidak bisa diprediksi. Hambatan yang bisa diprediksi seperti calon nasabah yang memilki usaha pertanian, akan terkena banjir, hama dan harga jual hasil tani yang rendah. Maka suveyor perlu menganalisis hambatan apa saja yang kemungkinan terjadi untuk menetapkan jumlah pembiayaan yang direkomendasikan. Hambatan yang tidak diprediksi seperti bencana alam dan pandemi yang saat ini terjadi. Mereka mengatasinya dengan keharusan mengasuransikan pembiayaannya ke penyedia jasa asuransi syariah.

7) Cash Flow (Arus Kas), merupakan aliran kas yang terjadi pada usaha atau tabungan calon nasabah. Pada instrumen arus kas yang diukur oleh BSI adalah pembukuan selama 2 tahun terakhir apabila pembiayaan mikro. Namun apabila pembiayaan mitra guna yang dilihat adalah mutasi rekening selama 3 bulan terakhir. Pada BPR Syariah juga lebih mengutamakan perputaran arus 
kas yang dimiliki oleh nasabah melalui data transaksi rekening selama 3 bulan terakhir.

8) Closeness (Kedekatan), merupakan pihak yang terkait dengan calon nasabah. Artinya perlu dilakukan analisis calon nasabah itu hasil rekomendasinya siapa dan asal usulnya bagaiamana. Indikator ini sangat penting karena dapat memunculkan informasi yang valid. Pada penelitian ditemukan bahwa lembaga kuangan syariah rata-rata menghindari calon nasabah yang berasal dari lingkungan kementerian hukum dan HAM (Kemenkumham) seperti hakim, jaksa dan juga menghindari calon nasabah dibawah naungan kementerian pertahanan yakni Tentara, Polisi dan lainnya. Pada sektor mikro BMT juga melihat asal usul nasabah apakah dari rekomendasi tokoh masyarakat atau tidaknya. Artinya tokoh yang memiliki pengaruh sudah memiliki integritas dan dipercaya oleh masyarakat. Kedekatan juga menjadi pertimbangan apabila ada calon nasabah yang memiliki hubungan terhadap karyawan. Artinya bisa jadi adanya komitmen untuk melakukan pembayaran apabila karyawan tersebut masih bekerja di lembaga, namun apabila sudah tidak bisa menjadi bermasalah karena adanya conflict of interest (konflik kepentingan).

Analisis lainnya melalui model analisis 7P yakni sebagai berikut:

1. Personality, pada komponen personal BMT Mubarakah menanyakan kepada rekan, dan tetangganya terkait perilaku.di BMT Mitra muamalat untuk menilai personal cukup sulit karena dibutuhkan pengalaman untuk menilai. Sebelum tahun 2019 masih dapat diakses melalui BI Checking, namun setelah tahun 2019 untuk mengakses BI checking maka harus menjadi anggota dari ototritas jasa keuangan. Ada beberapa personal yang masih dapat dibina maka dipertahankan, namun diberikan nominal pembiayaan yang lebih rendah dari sebelumnya.

2. Party (klasifikasi), berdasarkan analisis lembaga membagi calon nasabah/anggota berdasarkan segmentasi pasar dan penghasilannya. Di Undaan lebih banyak bekerja sebagai petani, maka pembiayaan yang dilakukan adalah model rekenening koran atau musiman, membayar ujroh atau bagi hasilnya saja setiap bulannya. Pada segmen pedagang, dapat digunakan pembiayaan dengan angsuran perbulan berupa angsuran pokok dan angsuran margin.

3. Purpose (tujuan), analis dari BMT dan Bank Syariah menanyakan keperluan pembiayaannya apakah untuk modal kerja (produktif) dan untuk konsumtif (pembelian barang). Tujuan dari calon nasabah sebagai acuan untuk diajukan kepada DPS akan menggunakan model akad apa sesuai dengan kebutuhan calon nasabah.

4. Prospect (Masa depan perusahaan/nasabah), harapan akan bisnis yang dibiayai oleh lembaga menjadi pertimbangan untuk jangka panjang, apakah usahanya nanti dapat bertumbuh secara konsisten ataukah stabil pada skala bisnis saat ini.

5. Payment (pembayaran), besarnya pembayaran angsuran setiap bulannya diperoleh darimana, apakah dari hasil usaha ataukah dari sisa pendapatan dari gaji. Gaji juga diperhitungkan apakah masih lajang ataukah sudah menikah. Apabila sudah menikah ada tanggungan lain tidak dari pasangannya. Apabila tidak ada tanggungan lain, apakah sepakat untuk jumlah gajinya digabungkan. 
Ada instrumen yang lebih aman melalui skema potong gaji pekerja, namun juga perlu diketahui kondisi calon nasabah tersebut, semakin besar kebutuhan dengan gaya hidup yang tinggi memberikan tekanan dan menimbulkan kesenjangan kesehatan.

6. Profitability (keuntungan), kemampuan calon anggota/nasabah dalam mencari laba menjadi indikator ketika dalam situasi yang diluar dugaan seperti pandemi ataupun krisis ekonomi masih dapat memperoleh laba atau tidaknya. Tentunya dalam kondisi yang diluar dugaan beberpa usaha pasti terdampak, namun kemampuan dari calon nasabah untuk mencari peluang lainnya ataupun laba lain yang diperoleh dari bidang usaha lain atau cara lain menjadi value added dalam menentukan kelayakan calon anggota/nasabah untuk di ACC.

7. Protection (Penjagaan pembiayaan), bagaimana menjaga pembiayaan yang dikucurkan oleh Bank Syariah maupun BMT ini merupakan kemampuan dari calon nasabah untuk menjaga amanah dana yang diberikan oleh bank untuk betul digunakan sesuai kebutuhan. Terkadang ada beberapa nasabah yang mengatakan untuk keperluan modal kerja usaha perdagangan dan lainnya namun ternyata untuk kebutuhan konsumtif. Hal ini akan menjadikan dana yang dikucurkan oleh Bank Syariah menjadi tidak produktif

Berdasarkan rumusan hasil penelitian, peneliti mendapatkan temuan baru yakni, analisis pembiayaan yang umumnya menggunakan 5C, dapat ditambahkan menjadi 8C sehingga lebih komprehensif dan akurat dalam menilai kelayakan pembiayaan. Penelitian ini melengkapi penelitian sebelumnya yang telah dilakukan oleh (Puspitasari \& Singgih, 2011), (Hamonang, 2020), (Ma'rur, 2020), penelitian itu hanya menganalisis penerapan 5C belum sampai pada 8C. Penelitian ini telah menganalisis pembiayaan yang diterapkan di Lembaga keuangan syariah yakni Bank Syariah, BPRS dan BMT menggunakan analisis 8C.

\section{PENUTUP}

Penelitian ini bertujuan memberikan rekomendasi analisis pembiayaan yang lebih akuran. Temuan penelitian ini adalah menemukan 3 variabel baru dalam menganalisis pembiayaan yakni, constrain (hambatan), cash flow (arus kas), closeness (kedekatan). Penelitian ini memberikan kontribusi kepada akademisi sebagai wawasan model analisis pembiayaan baru dengan menambah aspek analisis yang semula 5C menjadi 8C. Kontribusi bagi praktisi lembaga keuangan syariah dapat menjadikan pedoman analisis 8C dalam menentukan pembiayaan yang akurat. Keterbatasan penelitian ini belum menguji implementasi aspek 8C dalam skala yang lebih luas, masih pada wilayah karesidenan pati, yakni Kudus, Pati dan Blora. Rekomendasi penelitian selanjutnya dapat menguji implementasi aspek 8C ke lingkup yang lebih luas lagi. 


\section{REFERENSI}

Ali, H., \& Miftahurrohman. (2016). Determian yang Mempengaruhi Pembiayaan Murabahah Pada Perbankan Syariah di Indonesia. Jurnal Bisnis Dan Manajemen, 6(April), 31-44. https://doi.org/10.15408/ess.v6i1.3119

Allama, A., \& Nugroho, A. S. (2021). BSI Kudus.

Anwar, Z. (2021). BMT Al Amin.

Arief. (2021). BMT Mitra Muamalat.

Arifah, O. N. (2017). Analisis Pembiayaan Mudharabah Bermasalah Pada BMT Mitra Hasanah Semarang. Jurisprudence, 7(1), 40-46.

Djuarni, W. (2011). Analisis Perbandingan Metode Pemberian Kredit di Bank Konvensional dengan Pembiayaan Musyarakah di Bank Syariah pada PT Bank Jabar Banten dan PT Bank Jabar Syariah Tbk. Prosiding SNapp2011: Sosial, Ekonomi Dan Humaniora, 251-258.

Firdaus, R. N. (2015). Pengaruh Faktor Internal dan Eksternal Yang Mempengaruhi Pembiayaan Bermasalah Pada Bank Umum Syariah di Indonesia. El-Dinar, 3(1), 82-108.

Hadi, M. N. (2021). BPR Syariah Artha Mas Abadi.

Hamonang. (2020). Analisis Penerapan Prinsip 5C dalam Penyaluran Pembiayaan Pada Bank Muamalat KCU Padangsidempuan. JIMEA Jurnal Ilmiah MEA (Manajemen, Ekonomi Dan Akuntansi), 4(2), 454-466.

Hidayatullah, A. (2021). BPR Syariah Artha Mas Abadi.

Ibrahim, A., \& Rahmawati, A. (2017). Analisis Solutif Penyelesaian Pembiayaan Bermasalah di Bank Syariah : Kajian Pada Produk Murabahah di Bank Muamalat Indonesia Banda Aceh. IQTISHADIA: Jurnal Kajian Ekonomi Dan Bisnis Islam, 10, 71-96. https://doi.org/http://dx.doi.org/10.21043/iqtishadia.v10i1.2319

Ihsan. (2021). BMT Mubarakah.

Lusian, S., Siregar, H., \& Maulana, T. N. A. (2014). Analisis Faktor-Faktor Penyebab Pembiayaan Bermasalah di Bank Pembiayaan Rakyat Syariah XYZ Periode 20092013. Finance and Banking Journal, 16(1), 17-37.

Ma'rur, M. (2020). Prinsip 5C Sebagai Instrumen Utama dalam Analisis Pembiayaan (Studi Kasus di Koperasi Jasa Keuangan Syariah Baitul Mal Wat-Tamwil Nuasnsi Umat Cabang Ngoro). Islaminomics: Journal of Islamic Economics, Business and Finance, 10(1), 55-65.

Pato, S. (2013). Analisis Pemberian Kredit Mikro Pada Bank Syariah Mandiri Cabang Manado. Jurnal EMBA, 1(4), 875-885.

Puspitasari, M., \& Singgih, M. L. (2011). Analisa Dan Perbaikan Sistem Evaluasi Kelayakan Pengambilan Kredit di Bank Syariah X. Prosisding Seminar Nasional Manajemen Teknologi XIII.

Shella, \& Butanto, H. hadi. (2021). BPR Syariah Saka Dana Mulia.

Suratno. (2021). BMT Ar Raudloh.

Susilo, S., Hubeis, M., \& Purwanto, B. (2012). Pengaruh Karakteristik dan Perilaku UKM , serta Sistem Pembiayaan Terhadap Penyaluran Pembiayaan BNI Syariah. Manajemen IKM, 7(1), 1-9.

Yusuf, J. (2014). Analisa Kredit Untuk Credit (Account Officer) (Cetakan Ke). Jakarta: PT Gramedia Jakarta. 
Halaman ini sengaja dikosongkan 